\title{
ANALISIS PENERAPAN PSAK 50 DAN 55 ATAS IMPAIRMENT PIUTANG PADA PT. PUTRA KARANGETANG
}

\author{
Ismie Iswara Akun ${ }^{1}$, Herman Karamoy ${ }^{2}$, Meily Kalalo ${ }^{3}$ \\ ${ }^{1,2,3}$ Jurusan Akuntansi, Fakultas Ekonomi dan Bisnis, Universitas Sam Ratulangi, Jl. Kampus Bahu, Manado, \\ 95115, Indonesia
}

E-mail : ismieiswaraakun@gmail.com

\begin{abstract}
In conducting the sale of goods and services. The sale is made in cash and lending. Receivables arising from the sale or delivery of goods and services on credit are classified as trade receivables which are then not likely to change into receivables. And receivables may decrease in value over time. Research objectives to determine the extent to which the application of PSAK 50 \& PSAK 55 on impairment of receivables at PT. Putra Karangetang. The method used is descriptive research method. The result of the research can be concluded that during the last 3 (three) years there has been a decrease in the value of receivables, because PT. Son of Karangetang value of receivable there is a decline in value per year then it will be good for company. For the presentation process, recognition, measurement is in accordance with PSAK 50 \& 55 (revised 2014).
\end{abstract}

Keywords : presentation, recognition, measurement, impairment, receivables

\section{PENDAHULUAN}

Perusahaan melakukan berbagai cara untuk meningkatkan jumlah penjualannya agar mencapai keuntungan semaksimal mungkin. Selain meningkatkan kualitas dari barang atau jasa tersebut, perusahaan juga dapat melakukan penjualan secara kredit. Perusahaan yang bergerak di bidang distributor untuk produk tertentu atau barang campuran sebagian besar transaksi penjualannya dilakukan secara kredit. Kegiatan tersebut selain akan meningkatkan pangsa pasar (market share) dari produk tersebut, juga akan meningkatkan laba perusahaan seiring dengan peningkatan omset penjualannya.

Sistem akuntansi memperkenalkan "impairment" atau penurunan nilai atas piutang, penurunan nilai piutang dapat dihitung dengan dua cara yaitu; secara individu dan dihitung secara kolektif. Perhitungan penurunan nilai secara individu sifatnya memperhitung kasus per kasus berdasarkan probabilitas suatu kredit menjadi default. Sedangkan perhitungan secara kolektif adalah perhitungan penurrunan nilai asset keuangan yang signifikan tetapi individual tidak mengalami penurunan nilai.jadi kredit yang kualitasnya baik yang kelancaran pembayaran dan prospek usaha baik akan memperkecil jumlah penurunan nilai. Sementara disisi lain kredit yang kualitasnya kurang baik akan menjadi semakin besar penurunan nilainya.

Akuntansi bagi sebuah perusahaan sebagai mengontrol atau mengendali keuangan dalam perusahaan. Kegiatan ekonomi khususnya pada dunia bisnis, dengan adanya akuntansi perusahaan akan mengetahui pengelolahan dana, beberapa laba yang dimiliki, serta apakah ada kerugiagan dari aktifitas ekonomi perusahaan. Dari laporan pemimpin perusahaan bisa mengevaluasi bisnis yang dijalankan sekaligus mengidentifikasi masalah - masalah keuangan yang sedang dihadapi. Berperan dalam perencanaan perusahaan dimasa depan. Dengan adanya laporan keuangan yang dievaluasi maka seseorang pemimpin akan bisa dengan mudah melakukan perencanaan - perencanaan tertentu terkait masa depan perusahaannya.

Piutang usaha dikatakan aset karena piutang ini nantinya akan dapat "dicairkan" (di convert) dari piutang menjadi uang kas, sebagai hasil dari penagihan penjualan. Piutang 
usaha mencerminkan hak perusahaan untuk menagih kepada customer / pelanggan demi mendapatkan uang kas. Persedian dagangan merupakan aset karena nantinya akan dijual oleh perusahaan kepada pelanggan untuk mendapatkan piutang (tak menangih) maupun kas pada akhirnya (Hery, 2015:13). Piutang mengacu pada sejumlah tagihan yang akan diterima oleh perusahaan yang pada umumnya berbentuk kas dari pihak lain, baik dari sebagai akibat penyerahan barang dan jasa secara kredit untuk piutang pelanggan yang terdiri atas piutang usaha dan memungkinkan piutang wesel, memberikan pinjaman untuk piutang karyawan, piutang debitur yang biasanya langsung dalam bentuk piutang wesel, dan piutang bunga, maupun sebagai akibat kelebihan pembayaran kas kepada pihak lain untuk piutang pajak. Dalam hal ini penjualan perusahaan adalah pemberian kredit, sehingga PT. Putra Karangetang memiliki piutang.

\section{TINJAUAN PUSTAKA}

\subsection{Laporan Keuangan}

Akuntansi adalah proses identifikasi, pengumpulan, dan penyimpangan data serta proses pengembangan, pengukuran, dan komunikasi informasi. Berdasarkan definisi tersebut. Secara umum akuntansi dapat diartikan sebagai sistem informasi yang menyediakan laporan untuk para pemangku kepentingan mengenai aktivitas ekonomi dan kondisi perusahaan (Reeve. et, al. 2013:9).

Menurut PSAK No. 1 (2015: 1), "Laporan keuangan adalah penyajian terstruktur dari posisi keuangan dan kinerja keuangan suatu entitas". Laporan ini menampilkan sejarah entitas yang dikuantifikasi dalam nilai moneter.

Menurut Pernyataan Standar Akuntansi Keuangan (PSAK) No. 1 paragraf 08, 09, 10, 11 dan 12 (IAI, 2015) laporan keuangan yang lengkap terdiri dari:

a) Laporan posisi keuangan pada akhir periode;

b) Laporan laba rugi komprehensif selama periode;

c) Laporan perubahan ekuitas selama periode;

d) Laporan arus kas selama periode;

e) Catatan atas laporan keuangan, berisi ringkasan kebijakan akuntansi penting dan informasi penjelasan lainnya; dan

f) Laporan posisi keuangan pada awal periode komparatif yang disajikan ketika entitas menerapkan suatu kebijakan akuntansi secara retrospektif atau membuat penyajian kembali pos-pos laporan keuangan, atau ketika entitas mereklasifikasi pos-pos dalam laporan keuangannya.

\subsection{Tujuan Laporan Keuangan}

Tujuan khusus laporan keuangan adalah menyajikan secara wajar dan sesuai dengan prinsip-Tujuan Laporan Keuangan adalah menyadiakan informasi yang menyangkut posisi keuangan, kinerja serta perubahan posisi keuagan suatu perusahaan yang bermanfaat bagi sejumlah besar pemakai dalam pengambilan keputusan ekonomi. Tujuan laporan keuangan adalah memberikan informasi tentang posisi keuangan, kinerja dan perubahan posisi keuangan suatu perusahaan yang bermanfaat bagi sejumlah besar pemakai dalam pengambilan keputusan ekonomi, serta hasil yang dicapai selama periode tertentu. (Lili M. Sadeli, 2012:18).

\subsection{Piutang}

Piutang adalah sebagai suatu tuntutan atau tagihan atas sejumlah uang atau atas penerimaan pembayaran yang dimiliki oleh seseorang atau badan kepada orang atau badan lain. Sebagian besar piutang timbul dari penyerahan barang dan jasa secara kredit kepada pelanggan. Tidak dapat dipungkiri bahwa pada umumnya pelanggan akan menjadi lebih 
tertarik untuk membeli sebuah produk yang ditawarkan secara kredit oleh perusahaan, dan hal ini rupaya juga menjadi salah satu trik bagi perusahaan untuk meningkatkan besarnya omset penjualan yang akan tampak dalam laporan laba ruginya. Piutang yang timbul dari penjualan atau penyerahan barang dan jasa secara kredit ini diklasifikasikan sebagai piutang usaha yang kemudian tidak tertutup kemungkinan akan berganti menjadi piutang wesel (Hery, 2015:202).

\subsection{Konsep Penurunan Nilai}

Penurunan nilai adalah suatu kondisi dimana nilai tercatat aset melebihi nilai yang dapat diperoleh kembali. PSAK 55 mewajibkan adanya estimasi penurunan nilai asset keuangan atau disebut juga impairment. Untuk perusahaan pembiayaan, estimasi ini disebut cadangan penurunan piutang pembiayaan (CPPP). CPPP dihitung atas dasar nilai tercatat berdasarkan nilai biaya perolehan diamortisasi. Sesuai pedoman aplikasi PSAK 55 maka estimasi terdapat jumlah kerugian penurunan nilai dapat menghasilkan satu nilai kerugian atau kisaran nilai kerugian mungkin terjadi. Perusahaan pembiayaan harus mengakui kerugian akibat penurunan nilai sebesar estimasi terbaik dalam kisaran tersebut dengan mempertimbangkan seluruh informasi relevan yang tersedia sebelum laporan keuangan diterbitkan menganai kondisi yang terjadi pada tanggal neraca.

Penurunan nilai kolektif asset keuangan yang dicatat berdasarkan biaya diperoleh dan diamortisasi meliputi:

a. Kelompok asset keuangan sejenis yang tidak signifikan secara individual.

b. Asset keuangan yang signifikan secara individual yang tidak mengalami penurunan nilai berdasarkan bievaluasi secara individu.

Dalam melakukan penilaian secara kolektif, perusahaan harus menghitung:

a. Probability of default (PD): model ini menilai probabilitas konsumen gagal melakukan pembayaran kembali secara penuh dan tepat waktu.

b. Recoverable amount: berdasarkan identifikasi arus kas masa datang dan estimasi nilai kini dari arus kas tersebut.

c. Loss given default (LGD): perusahaan mengestimasi kerugian ekonomis yang mungkin akan diderita perusahaan apabilah terjadi tunggakan fasilitas kredit/pembiayaan. LGD menggambarkan jumlah hutang yang tidak dapat diperoleh kembali dan umumnya ditunjukan pada presentase dari exposure at default (EAD). Model perhitungan LGD mempertimbangkan jenis peminjam, fasilitas dan mitigasi resiko, misalnya keterbatasan angunan.

d. Loss identification period (LID): periode waktu antara terjadi peristiwa yang merugikan dalam kelompok asset keuangan sampai bukti objektif dapat diidentifikasi atas kredit/pembiayaan secara individual.

e. Exposure at default (EAD): perusahaan mengestimasi tingkat utilisasi yang diharapkan dari fasilitas kredit/pembiayaan pada saat terjadi tunggakan.

Kerugian penurunan nilai diakui pada laporan laba rugi dan nilai tercatat asset keuangan atau kelompok asset keuangan tersebut dikurangi dengan kerugian penurunan nilai yang terbentuk. Jika periode berikutnya jumlah penurunan nilai berkurang dan penurunan dapat dikaitkan secara objektif pada peristiwa terjadi setelah penurunan nilai tersebut diakui (seperti meningkatnya peringkat kredit debitur atau penerbit), kerugian penurunan nilai yang sebelumnya diakui dipulihkan melalui laporan laba rugi hingga nilai tercatat asset keuangan pada tanggal pemulihan penurunan nilai tidak melebihi biaya perolehan diamortisasi sebelum pengakuan kerugian penurunan nilai dilakukan. Pada saat kerugian penurunan nilai diakui, pendapatan bungga diakui berdasarkan nilai tercatat setelah kerugian penurunan nilai dengan menggunakan suku bunga yang digunakan untuk mendiskonto estimasi arus kas masa datang pada saat menghitung penurunan nilai. 
Berdasarkan Bulletin teknis Nomor 4 tentang ketentuan transisi saat awal penerapan PSAK 55yang dibuat oleh IAI. estimasi menentukan penurunan nilai instrument keuangan berdasarkan kondisi pada saat itu. Selisi antara penurunan nilai ini dengan penurunan nilai yang ditentukan berdasarkan prinsip akuntansi yang berlaku sebelumnya diakui langsung kesaldo laba pada saat awal penerapan PSAK 55. Maka entitas memisahkan penurunan nilai yang bersal pada periode sebelumnya diakui langsung ke saldo laba, jika entitas tidak dapat memisahkan penurunan nilai tersebut pada penurunan nilai diakui dalam laporan laba rugi dan fakta tersebut diungkapkan secara memadai dalam catatan atas laporan keuangan.

\subsection{PSAK $50 \& 55$}

Laporan keuangan perusahaan di Indonesia menerapkan revisi berikut ini:

PSAK 50 Instrumen Keuangan: Penyajian.

PSAK 55 Instrumen Keuangan: Pengakuan dan Pengukuran.

PSAK 50 menghasilkan pengungkapan prinsip penyajian instrument keuangan, sebagai liabilitas atau ekuitas, saling hapus asset keuangan dan liabilitas keuangan. Pernyataan ini juga membantu perusahaan mengklasifikasikan instrument keuangan dalam asset keuangan, liabilitas keuangan, instrument ekuitas, termaksud juga klasifikasi yang terkait dengan bunga, deviden kerugian dan keuntungan dan keadaan dimana asset keuangan dan liabilitas keuangan saling hapus

PSAK 55 memberikan panduan atau mengatur prinsip-prinsip dasar pengakuan dan pengukuran asset keuangan, kewajian keuangan dan kontrak pembelian atau penjualan item non-keuangan. Selain kedua PSAK menjadi pembahasan utama dalam penelitian ini, telah terbit juga PSAK 60 (revisi 2010) mengenai instrument keuangan : kengungkapan. Tujuan terbitnya adalah mensyaratkan entitas untuk menyediakan pengungkapan dalam laporan keuangan yang memungkinkan para pengguna untuk mengevaluasi:

Signifikasi instrument keuangan terhadap posisi dan kinerja keuangan perusahaan

Sifat dan luas reesiko yang timbul dari instrument keuangan yang mana akan perusahaan sajikan selama periode dan pada akhir periode dan bagaimana entitas mengelolah resiko tersebut.

\subsection{Aset Keuangan}

Aset keuangan diklasifikasikan ke dalam asset keuangan yang diukur pada nilai wajar melalui laporan laba rugi (FVTPL) asset keuangan dimiliki hingga jatuh tempo (HTM), asset keuangan tersedia untuk dijual (AFS) atau pinjaman diberikan dan piutang. Klasifikasi ini tergantung dari sifat dan tujuan perolehan asset keuangan tersebut dan ditentukan pada saat awal pengakuannya.

1. Asset keuangan atau kewajiban keuangan yang diukur pada nilai wajar melalui laporan laba rugi (FVTPL). Asset keuangan diklasifikasikan dalam FVTPL, jika asset keuangan sebagai kelompok diperdagangkan atau pada saat pengakuan awal ditetapkan untuk diukur pada FVTPL. Asset keuangan diklasifikasikan sebagai diperdagangkan apabila: asset keuangan atau kewajiban keuangan yang termaksud dalam kategori ini harus memenuhi sala satu kondisi beriut:

a. Diperoleh atau dimiliki terutama untuk tujuan dijual/dibeli kembali dalam waktu dekat.

b. Merupakan derivative

c. Merupakan bagian dari portopolio instrument keuangan tertentu yang dikelola bersama dan terdapan bukti mengenai pola ambil untang dalam jangka pendek.

Asset keuangan selain asset keuangan diperdagangkan dapat ditetapka sebagai FVTPL pada saat pengakuan awal jika: 

a. Penetapan tersebut mengeliminasi atau mengurangi secara signifikan ketidakkonsistenan pengukuran dan pengakuan yang dapat timbul
b. Asset keuangan merupakan bagian dari kelompok asset keuangan atau kewajiban atau keduanya, yang dikelolah dan kinerjanya berdasarkan nilai wajar, sesuai dengan dokumentasi manajemen resiko atau strategi investasi perusahan dan informasi tentang kelompok disediakan secara internal kepada manajemen kunci melekat dan PSAK 55 memperoleh kontrak gabungan (asset atau kewajiban ) ditetapkan sebagai FVTPL.
c. Merupakan bagian dari kontrak yang mengandung satu atau dua derivative

2. Investasi dalam kelompok dimiliki singga jatuh tempo (HTM).

Asset keuangan diklasifikasikan sebagai investasi dalam kelompok dimiliki hingga jatuh tempo hanya jika investasi tersebut memiliki pembayaran yang tetap atau lebih ditentukan dan jatuh temponya telah ditetapkan serta intitas mempunyai intense positif dan kemampuan untuk memiliki asset keuangan tersebut hingga jatuh tempo. Pada saat pengakuan awal investasi dimeliliki hingga jatuh tempoh diukur pada nilai wajar ditambah dengan nilai transaksi yang dapat diatribusikan secara langsung dengan perolehan asset keuangan. Setelah pengakuan awal investasi memiliki hingga jatuh tempo diukur dengan biaya perolehan diamortisasi dengan mengunakan metode suku bunga efektif dikurangi kerugian penurunan nilai yang ada.

3. Asset Keuangan yang diklasifikasikan dalam kelomopok tersedia untuk dijual.

Asset keuangan yang tidak diklasifikasikan sebagai dimiliki hingga jatuh tempo, diukur pada nilai wajar melalui laporan laba rugi atau pinjaman yang diberikan dan piutang yang diklasifikasikan sebagai tersedia untuk dijual. Pada saat pengakuan awal, asset keuangan tersedia untuk dijual diukur pada nilai wajar ditambah dengan biaya transaksi yang dapat diatribusikan secara langsung dan selanjutnya diukur pada nilai wajar, dimana keuntungan atau kerugian pada perubahan nilai wajarnya dilaporkan pada komponen yang terpisah pada ekuitas sampai pada saat asset keuangan tersebut diselesaikan dan akumulasi keuntungan dan kerugian tersebut diakui pada laporan laba rugi.

4. Pinjaman yang diberikan dan Piutang.

Kas dan setara kas, investasi neto sewa pembiayaan, piutang pembiayaan konsumen, tagian anjak piutang dan piutang lain-lainnya dengan pembayaran tetap atau ditentukan dan tidak mempunyai kuotasi dipasar aktif diklasifikasi sebagai "pinjaman yang diberikan dan piutang". Pada saat pengakuan awal pinjaman yang diberikan dan piutang diukur pada nilai wajar ditambah dengan biaya transaksi yang dapat diatribusikan secara langsung dengan perolehan asset keuangan dan selanjutnya diukur pada biaya perolehan diamortisasi dengan mengunakan metode suku bunga yang efektif, kecuali piutang jangka pendek dimana pengakuan bunganya tidak material.

Pada saat pengakuan awal (initial measurement), entitas mengukur pada nilai wajarnya. Dalam asset keuangan tidak diukur pada nilai wajar melalui laporan laba rugi, nilai wajar tersebut ditambah dengan biaya transaksi yang dapat diatribusikan secara langsung dengan perolehan atau penerbitan asset keuangan tersebut, misalnya fee and commission. Adapun untuk pengukuran selanjutnya (subsequent measurement), entitas pengukuran asset keuangan. Berdasarkan 4 kategori klasifikasi asset keuangan yang telah dijelaskan sebelumnya. Untuk instrument keuangan seperti HTM dan Loans and receivables. Biaya transaksi dimasukan dalam perhitungan biaya perolehan amortisasi menggunakan metode suku bunga efektif dan selanjutnya akan diamortisasi melalui laporan laba rugisepanjang umur instrument tersebut. Untuk AFS, biaya transaksi diakui dalam ekuitas sebagai bagian dari perusahaan nilai wajar pada penilaian kembali. 
Instrument keuangan diukur pada pengakuan awal sebesar nilai wajar ditambah dengan biaya transaksi kecuali untuk instrument yang diukur dengan mengunakan nilai wajar. Penghapusan aset keuangan didasarkan atas kombinasi risk and reward dan pengendalian. risk and reward dilakukan sebelum evaluasi atas transfer pengendalian. Pengakuan gain/loss atas penghapusan liabilitas keuangan ketika utang baru diterbitkan memiliki persyaratan yang berbeda dengan utang lama. Restrukturisasi utang yang menyebabkan modifikasi subtansial term dapat menghasilkan gain/loss pada saat penerbitan liabilitas baru.

Rasio aktivitas merupakan rasio yang digunakan untuk mengukur efektifitas perusahaan dalam menggunakan aset yang dimilikinya, termaksud untuk mengukur tingkat efisiensi perusahaan dalam memanfaatkan sumber daya yang ada. Rasio ini juga digunakan untuk menilai kemampuan perusahaan dalam melaksanakan aktivitas sehari-hari. Jenis-jenis rasio aktivitas untuk mengukur kemampuan perusahaan dalam menggunakan dan mengoptimalkan aset yang dimilikinya, yaitu: Perputaran piutang usaha, Perputaran persediaan, Perputaran modal kerja, Perputaran aset tetap, Perputaran total aset. Dan dalam perusahaan menggunakan perputaran piutang usaha.

Rumus yang digunakan untuk menghitung rasio perputaran piutang usaha dan lamanya ratarata penagihan piutang usaha:

Rasio perputaran piutang $=$ penjualan kredit

(piutang usaha awal thn + piutang usaha akhir thn):2

$$
\text { Rasio perputaran piutang }=\frac{\text { penjualan kredit }}{\text { rata-rata piutang usaha }}
$$

Lamanya rata-rata penagihan piutang usaha $=$

365 hari

rasio perputaran piutang usaha

\subsection{Penelitian Terdahulu}

1. Penelitian yang dilakukan Febriati (2013) hasil penelitiannya menunjukkan bahwa dalam pengakuan dn pengukuran cadangan kerugian penurunan nilai (CKPN) yang diterapkan PT. BANK Rakyat Indonesia. Tbk telah sesuai dengan PSAK 55 (revisi 2011).

2. Penelitian yang dilakukan Pulumbara (2014) hasil penelitiannya menunjukkan bahwa dalam proses penyajian, pengakuan, pengukuran dan penentuan cadangan kerugianpenurunan nilai pada PT. BANK Central Asia Tbk telah mengacu pada PSAK $50 \& 55$.

\section{METODE PENELITIAN}

\subsection{Jenis dan Sumber Data}

Jenis Penelitian yang digunakan penulis adalah Penelitian Deskriptif kualitatif. Penelitian deskriptif yaitu dengan mengumpulkan data, disusun, diinterprestasikan dan dianalisis sehingga memberikan kesimpulan yang jelas dan objektif terhadap masalah yang ada. Sumber data yang digunakan dalam penelitian yaitu sebagai berikut:

1. Data Primer adalah data yang dikumpulkan oleh peneliti yaitu dengan cara wawancara, dan data yang diambil dari perusahaan seperti sejarah, visi misi, data laporan keuangan dan data piutang (Sunyoto,2013:21). 
2. Data Sekunder adalah data yang berasal dari sumber catatan atau pengamatan lain. Contohnya: buku-buku literatur yang digunakan sebagai acuan, jurnal penelitian yang berkaitan dengan penurunan nilai piutang (Sunyoto,2013:21)

\subsection{Metode Analisis Data}

Metode yang digunakan dalam menganalisis data yang diperoleh adalah deskriptif yaitu untuk mengumpulkan, menyusun, menganalisis data, memperoleh gambaran sebenarnya bagaimana penerapan PSAK 50 \& 55 tentang penurunan nilai piutang pada perusahaan untuk kemudian dibandingkan dengan teori yang ada sehingga mampuh memberikan informasi yang lengkap bagi pemecahan masalah yang dihadapi.

\section{HASIL ANALISIS DAN PEMBAHASAN}

\subsection{Hasil Analisis}

\subsubsection{Kebijakan Akuntansi Perusahaan}

PT. Putra Karangetang adalah perusahaan yang bergerak dibidang industri makanan seperti tepung kelapa. Sebagaimana diatur dalam PSAK 50 (revisi 2014) instrument keuangan : Penyajian paragraph 13-14 kontrak dan kontraktual mengacu pada suatu perjanjian antara dua pihak atau lebih yang memiliki kosekuensi ekonomik yang jelas dan kecil peluangnya akan diabaikan oleh pihak - pihak yang terlibat, umumnya karena pemenuhan perjanjian ini dapat dipaksakan secara hukum. Entitas termaksud perusahaan perorangan, persekutuan, badan hukum, wali amanah dan institusi pemerintah. PSAK 55 (revisi 2014) instrument keuangan : Pengakuan dan Pengukuran paragraph 05 pada kontrak pembeli atau penjual item nonkeuangan yang dapat diselesaikan secara neto dengan kas atau instrument keuangan lain seolah - olah kontrak tersebut adalah instrument keuangan, dengan pengecualian untuk kontrak yang disepakati dan dimaksudkan untuk terus dimiliki dengan tujuan untuk menerima dan menyerahkan item nonkeuangan sesuai persyaratan pembelian, penjualan atau penggunaan yang diperkirakan.

\subsubsection{Akibat Timbulnya Penurunan Nilai Piutang}

Dalam pemberian jasa secara kredit kepada pelanggan PT. Putra Karangetang juga melakukan pertimbangan-pertimbangan dan analisa sehingga harus ada kesepakatan dalam konfirmasi pada pelanggan agar PT. Putra Karangetang memiliki bukti dan dasar penangihan. Namun pada kenyataannya tidak bisa dihindari adanya suatu resiko dimana timbul piutang tak tertagih. Piutang tak tertagih ini oleh PT. Putra Karangetang akan di cadangkan sebagai kerugian piutang dan merupakan penambahan atas akun cadangan kerugian piutang.

PT. Putra Karangetang menyatakan bahwa dalam melakukan identifikasi pada piutang mengalami penurunan nilai pada piutang terjadi pada setiap akhir periode laporan keuangan.

Penurunan nilai diukur berdasarkan besarnya nilai tercatat dengan jumlah terpulihkan. Perusahaan melakukan evaluasi individual dan terdapat bukti objektif bahwa memang benar piutang tersebut mengalami penurunan nilai. Penurunan nilai secara individual dihitung dengan mengunakan metode diskonto arus kas, maka penurunan nilai dicatat sebagai cadangan penurunan nilai piutang. 


\subsubsection{Data Piutang pada PT. Putra Karangetang}

Data yang diperoleh mengenai kondisi piutang pada PT. Putra Karangetang selama 3 (tiga) tahun terakhir:

Table 4.1

Daftar piutang PT. Putra Karangetang

\begin{tabular}{|l|l|l|l|}
\hline & \multicolumn{1}{|c|}{$\mathbf{2 0 1 4}$} & \multicolumn{1}{|c|}{$\mathbf{2 0 1 5}$} & \multicolumn{1}{c|}{$\mathbf{2 0 1 6}$} \\
\hline Pendapatan & 11.555 .226 .906 & 12.505 .524 .806 & 11.162 .057 .612 \\
Piutang & 536.381 .586 & 6.641 .075 & 5.058 .135 \\
\hline
\end{tabular}

Sumber : Data Olahan (2017)

Untuk mendapatkan gambaran tentang berapa kali secara rata-rata piutang yang dikumpulkan dalam satu tahun piutang itu terjadi atau timbul dan diterima pembayaran dalam suatu periode tertentu dapat digunakan rumus rasio. Rasio ini diperoleh dengan membagi penjualan kredit tahunan perusahaan dengan rata-rata saldo piutang untuk periode yang sama untuk perputaran piutang pada PT. Putra Karangetang. Rumus rasio ini adalah:

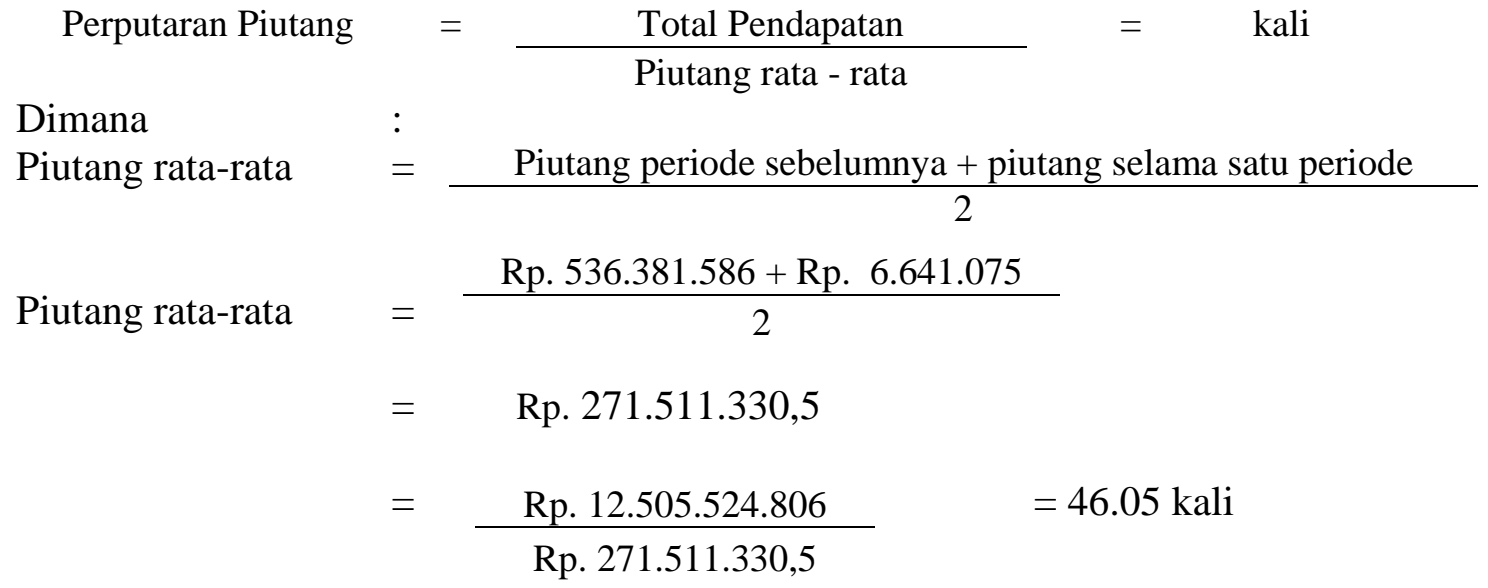

Tabel 4.1 diatas merupakan menjelaskan tentang penurunan nilai yang terjadi pada tahun 2014, tahun 2015 tahun 2016 . Untuk semua penjelasan diatas pada tahun 2014 tahun 2015 dan tahun 2016 telah mengalami penurunan nilai pada piutang pertahunnya. Ayat jurnal yang dibuat PT. Putra Karangetang oleh penjualan pada saat melakukan transaksi yaitu:

$\begin{array}{lll}\text { 1. } & \text { Piutang Dagang } & \mathrm{xxx} \\ & \text { Penjualan } & \mathrm{xxx} \\ \text { 2. } & \text { Harga Pokok Penjualan } & \mathrm{xxx} \\ & \text { Persediaan } & \mathrm{xxx}\end{array}$

Sesuai dengan PSAK 55 Entitas pada setiap akhir periode pelaporan, entitas mengevaluasi apakah terdapat bukti efektif bahwa aset keuangan atau kelompok aset keuangan mengalami penurunan nilai. Penurunan nilai yaitu suatu kondisi dimana terdapat bukti obyektif terjadinya peristiwa yang merugikan akibat satu atau lebih peristiwa yang terjadi setelah pengukuran awal aset tersebut dan peristiwa merugikan yang berdampak pada estimasi arus kas masa datang aset keuangan yang dapat diestimasi secara handal. Pengukuran tersebut dilakukan secara individual maupun kolektif.

Pada perusahaan penurunan nilai piutang pada setiap tahun berkurang karena kualitas produk ditingkatkan. Penurunan nilai terjadi di karenakan ada cadangan 
kerugian piutang, karena semakin banyak cadangan maka terlihat semakin sedikit bekurang piutang. Setelah meneliti berdasarkan data yang diperoleh maka menunjukan hasil bahwa penurunan nilai dibuat pada PT. Putra Karangetang. Bahwa penurunan nilai yang diakui dan dibuat oleh PT. Putra Karangetang. telah sesuai dengan Pernyataan Standar Akuntansi Keuangan (PSAK) No. 50 \& 55 (revisi 2014) tentang "penurunan nilai piutang".

\subsection{Pembahasan}

\subsubsection{Analisis Penerapan PSAK 50 \& 55 atas Impairment Piutang pada PT. Putra Karangetang}

\section{Tabel 4.2}

Perbandingan PSAK 50 \& 55 Penurunan Nilai pada PT. Putra Karangetang

\begin{tabular}{|c|c|c|}
\hline $\begin{array}{l}\text { Berdasarkan PSAK } 50 \text { \& } 55 \\
\text { (revisi 2014) }\end{array}$ & $\begin{array}{lll}\text { Berdasarkan } & \text { PT. } & \text { Putra } \\
\text { Karangetang } & & \\
\end{array}$ & Kesimpulan \\
\hline Pengakuan Laporan Keuangan & $\begin{array}{l}\text { Perusahaan melakukan } \\
\text { penyajian posisi nilai piutang } \\
\text { pada laporan keuangan. }\end{array}$ & $\begin{array}{l}\text { Sesuai. Karena Perusahan } \\
\text { melakukan cara penyajikan } \\
\text { piutang pembiayaan dan } \\
\text { cadangan penurunan nilai } \\
\text { piutang pada laporan posisi } \\
\text { keuangan. }\end{array}$ \\
\hline $\begin{array}{lrr}\text { Penurunan nilai yaitu } & \text { kondisi } \\
\text { yang terdapat bukti } & \text { obyektif } \\
\text { terjadinya peristiwa } & \text { yang } \\
\text { merugikan. } & & \\
\end{array}$ & $\begin{array}{l}\text { Pada setiap akhir periode } \\
\text { Penurunan nilai diukur } \\
\text { berdasarkan besarnya nilai } \\
\text { tercatat dengan jumlah } \\
\text { terpulihkan. }\end{array}$ & $\begin{array}{l}\text { Sesuai. Karena Perusahaan } \\
\text { melakukan evaluasi individual } \\
\text { dan terdapat bukti objektif } \\
\text { bahwa memang benar piutang } \\
\text { tersebut mengalami penurunan } \\
\text { nilai. }\end{array}$ \\
\hline $\begin{array}{l}\text { Mengestimasi jumlah kerugian } \\
\text { penurunan nila terjadi. }\end{array}$ & \begin{tabular}{lr} 
Proses penilaian & penurunan \\
nilai diakui & dengan \\
mempertimbangkan & \\
pengalaman & untuk \\
menyesuaikan data yang dapat \\
di observasi r dan \\
mempertimbangkan dokumen \\
\multicolumn{2}{l}{ yang diberikan oleh debitur. }
\end{tabular} & $\begin{array}{l}\text { Sesuai. Karena penilaian } \\
\text { penuruan nilai diakui dengan } \\
\text { mempertimbangkan dokumen } \\
\text { yang diberikan. }\end{array}$ \\
\hline $\begin{array}{l}\text { Derivatif melekat terhadap } \\
\text { penurunan nilai, aset keuangan } \\
\text { dikelompokan harus memiliki } \\
\text { kesamaan karakteristik resiko } \\
\text { kredit yang mengidentikasikan } \\
\text { kemampuan debitur untuk } \\
\text { membayar seluruh utang yang } \\
\text { jatuh tempo sesuai persyaratan } \\
\text { kontrak. }\end{array}$ & $\begin{array}{l}\text { Aset keuangan diakui } \\
\text { berdasarkan } \\
\text { resiko kredit atau kemampuan } \\
\text { debitur dalam } \\
\text { hutangnya yang akan jatuh } \\
\text { tempo sesuai } \\
\text { kontrak }\end{array}$ & $\begin{array}{l}\text { Sesuai. Karena dalam } \\
\text { pengakuan aset keuangan sama- } \\
\text { sama didasarkan pada } \\
\text { karakteristik resiko kredit yang } \\
\text { mengidentikasikan kemampuan } \\
\text { debitur untuk membayar } \\
\text { seluruh hutang sesuai perjanjian } \\
\text { kontrak. }\end{array}$ \\
\hline
\end{tabular}




\begin{tabular}{|c|c|c|}
\hline $\begin{array}{l}\text { Berdasarkan PSAK } 50 \text { \& } 55 \\
\text { (revisi 2014) }\end{array}$ & $\begin{array}{lll}\begin{array}{l}\text { Berdasarkan } \\
\text { Karangetang }\end{array} & \text { PT. } & \text { Putra } \\
\end{array}$ & Kesimpulan \\
\hline $\begin{array}{l}\text { Penilian Arus kas dimasa depan } \\
\text { dari kelompok aset keuangan } \\
\text { yang penurunan nilainya } \\
\text { dievaluasi secara kolektif, } \\
\text { diestimasi berdasarkan kerugian } \\
\text { kerugian historis yang pernah } \\
\text { dialami. }\end{array}$ & $\begin{array}{l}\text { Penurunan nilai yang telah } \\
\text { dikelompokan dan dievaluasi } \\
\text { secara kolektif berdasarkan } \\
\text { kerugian historis atas aset } \\
\text { keuangan. }\end{array}$ & $\begin{array}{l}\text { Sesuai. Karena Penurunan nilai } \\
\text { yang telah dikelompokan dan } \\
\text { dievaluasi secara kolektif } \\
\text { berdasarkan kerugian historis } \\
\text { yang pernah diamai perusahaan. }\end{array}$ \\
\hline
\end{tabular}

Sumber : Data Olahan (2017)

Tabel 4.2 Merupakan tabel memperlihatkan perbandingan yang terjadi antara penurunan nilai berdasarkan pernyataan Standar Akuntansi Keuangan (PSAK) No. 50 \& 55 revisi 2014 dengan penurunan nilai piutang pada PT. Putra Karangetang. Berdasarkan data yang diperoleh maka perbandingan tersebut menunjukan hasil bahwa PT. Putra Karangetang penurunan nilai yang diakui dan dibuat oleh PT. Putra Karangetang telah sesuai dengan Pernyataan Standar Akuntansi Keuangan (PSAK) No. 50 \& 55 revisi 2014 tentang penurunan nilai. PT. Putra Karangetang menyatakan bahwa setiap akhir periode penurunan nilai diukur berdasarkan besarnya nilai tercatat dengan jumlah terpulihkan, hal ini sesuai dengan Pernyataan Standar Akuntansi keuangan (PSAK) 50 \& 55 revisi 2014 yaitu pada setiap akhir periode Perusahaan melakukan evaluasi individual dan terdapat bukti objektif bahwa memang benar piutang tersebut mengalami penurunan nilai.

Pada Laporan Keuangan PT. Putra Karangetang melakukan penyajian posisi nilai piutang pada laporan keuangan, hal ini Sesuai dengan Pernyataan Standar Akuntansi keuangan (PSAK) $50 \& 55$ revisi 2014 Karena Perusahaan melakukan cara penyajikan piutang pembiayaan dan cadangan penurunan nilai piutang pada laporan posisi keuangan.5.

\section{KESIMPULAN DAN SARAN}

\subsection{Kesimpulan}

Berdasarkan hasil peelitian dan pembahasan dalam penelitian ini maka dapat disimpulkan sebagai berikut:

Berdasarkan Pernyataan Standar Akuntansi Keuangan (PSAK) No. 55 (revisi 2014) dapat disimpulkan bahwa selama 3 (tiga ) tahun terakhir telah terjadi penurunan nilai piutang sesuai dengan standar yang berlaku. Karena PT. Putra Karangetang nilai piutangnya terjadi penurunan nilai pertahun maka hal itu akan baik bagi perusahaan.

1. Penyajian, PT. Putra Karangetang sudah melakukan cara apa yang harus dipakai perusahaan dalam penyajikan piutang di laporan posisi keuangan. Perusahaan melakukan cara penyajikan piutang pembiayaan dan cadangan penurunan nilai piutang pada laporan posisi keuangan.

2. Pengakuan, PT. Putra Karangetang mengakui aset keuangan atau liabilitas keuangan dalam laporan posisi keuangan. Perusahaan melakukan penilaian setiap tanggal neraca untuk mengantisipasi kemungkinan terjadinya penurunan nilai yang timbul atas aset keuangan.

3. Pengukuran, Dalam proses estimasi penurunan nilai mempertimbangkan eksposur pinjaman yang diberikan dan bukan hanya yang berkualitas rendah. 
Metode yang dipakai untuk pengukuran pencatatan penurunan nilai adalah metode pencadangan dan asumsi yang digunakan dalam estimasi aset dimasa depan akan dikaji ulang secara berkala untuk mengurangi jumlah kerugian.

Untuk proses penyajian, pengakuan, pengukuran telah sesuai dengan PSAK 50 \& 55 (revisi 2014).

\subsection{Saran}

Saran yang dapat diberikan dalam penelitian ini yaitu :

1. Diharapkan PT. Putra Karangetang dapat melakukan penyesuain jika terjadi perubahan terhadap Pernyataan Standar Akuntansi Keuangan (PSAK) yang berlaku tentu saja akan sangat membantu perusahaan dalam meningkatkan kualitas laporan keuangan dan dapat menghasilkan laporan keuangan yang akurat dan terpercaya.

2. Untuk peneliti selanjutnya diharapkan agar dapat melakukan penelitian yang lebih luas mencakup kerugian penurunan nilai pada perusahaan.

\section{DAFTAR PUSTAKA}

Deisye Pulumbara, 2014. Analisis Penerapan PSAK 50 \& 55 atas cadangan keugian penurunan nilai PT.Bank Sentral Asia. Jurnal Fakultas Ekonomi dan Bisnis Universitas Sam Ratulangi Manado.

Dewan Standar Akuntansi (2013) exposure draft (ED) PSAK 50 (revisi 2010) Instrumen Keuangan: Penyajian. IAI: www.iaiglobal.or.id.

Donald E. Kieso, Jerry J Weygandt, \& Terry D. Werfield 2007, Akuntansi Intermedite / Edisi Keduabelas / jilid 1, Ciracas, Jakarta.Edition, 3 rd ed, USA : Wiley, 2015.

Febriati, CiptaniEkaputri. 2013 Analisis Penerapan PSAK 55 Atas Cadangan Kerugian Penurunan Nilai. Jurnal. Fakultas Ekonomi dan Bisnis Universitas Sam Ratulangi Manado.

Hery, 2015, Pengantar akuntansi Comprehensive Edition, PT. Grasindo: Jakarta.

Ikatan Akuntansi Keuangan. (2014). Standar Akuntansi Keuangan - PSAK 50 (revisi 2014). Instrument keuangan : Penyajian dan Pengungkapan. Jakarta: Salemba Empat

Ikatan Akuntansi Keuangan. (2014). Standar Akuntansi Keuangan - PSAK 55 (revisi 2014). Instrument keuangan : Pengakuan dan Pengukuran. Jakarta: Salemba Empat

Lili M. Sadeli, 2012, Dasar - Dasar Akuntansi, Jakarta, Penerbit: PT. Bumi Aksara.

Pontoh, Winston. 2013. Akuntansi Konsep dan Aplikasi. Indeks. Jakarta.

Smith J. Skousen, 2014, Intermediate Accounting, Western of Thomas Learning, South California.

Soemarso S. R. 2011, Revisi Akuntansi Suatu Pengantar, Penerbit Salemba Empat Jakarta.

Sunyoto Danang, 2013. Metode Penelitian Akuntansi. Indeks. Jakarta.USA: Cengage Learning, 2017

Warren, Carl S., James M. Reeve, and Jonathan Duchac. Financial Accounting. 15 th ed. Weygent, Jerry J., Paul D Kimmel, and Donald E. Kieso. Financial Accounting IFRS 